\title{
Praktyczne możliwości pokrycia ochroną ubezpieczeniową na polskim rynku szkód wyrządzonych w środowisku - wybrane zagadnienia
}

Wstęp

Zgodnie z ustawą z dnia 13 kwietnia 2007 r. o zapobieganiu szkodom w środowisku i ich naprawie ${ }^{1}$ podmiot odpowiedzialny za szkodę $\mathrm{w}$ środowisku zobowiązany jest do przywrócenia środowiska do stanu sprzed szkody. Problem odpowiedzialności za owe szkody dotyczy przede wszystkim przedsiębiorców i samorządów. Proste do zidentyfikowania są potencjalne szkody środowiskowe w przypadku przedsiębiorców prowadzących działalność związaną m.in. z przetwarzaniem odpadów, recyklingiem, produkcją artykułów chemicznych czy tworzyw sztucznych. Równie łatwo ryzyko wystąpienia takowych szkód rozpoznają samorządy, które odpowiadają chociażby za funkcjonowanie oczyszczalni ścieków czy składowisk odpadów, o czym dobitnie przypomniały niedawne zdarzenia w zakładzie „Czajka” w Warszawie². Nieoczywiste, często

${ }^{1}$ T.j. Dz.U. 2020, poz. 2187; dalej: u.z.s.ś.n.

${ }^{2}$ Zob. na ten temat: Pilne! Kolejna awaria w oczyszczalni ścieków „Czajka” w Warszawie, 11.12.2020, Państwowe Gospodarstwo Wodne „Wody Polskie”, [online:] https://www.wody. gov.pl/aktualnosci/1290-pilne-kolejna-awaria-w-oczyszczalni-sciekow-czajka-w-warszawie [dostęp: 29.12.2020]. Na temat poprzednich awarii: Natychmiastowa reakcja Ministerstwa na 
nierozpoznane ryzyko wyrządzenia omawianych szkód ponoszą jednak w zasadzie wszyscy przedsiębiorcy i wszystkie samorządy. Nawet prozaiczne awarie systemów wodociągowych czy kanalizacyjnych lub wypadek środka transportu mogą spowodować konieczność naprawienia szkód w środowisku.

Niniejszy artykuł poświęcony jest możliwości pokrycia ochroną ubezpieczeniową (na polskim rynku) szkód wyrządzonych w środowisku. Z punktu widzenia potencjalnego sprawcy kluczowe będzie zdefiniowanie samej szkody, jej rodzajów oraz rodzajów ubezpieczenia wraz z ich szczegółowym zakresem.

\section{Odpowiedzialność ustawowa}

W prawie cywilnym szkoda jest podstawową przesłanką odpowiedzialności odszkodowawczej, nie została wszakże zdefiniowana ani w ustawie z dnia 23 kwietnia 1964 r. - Kodeks cywilny ${ }^{3}$, ani w żadnym innym akcie prawnym na gruncie prawa cywilnego. W związku $\mathrm{z}$ tym $\mathrm{w}$ doktrynie i orzecznictwie pojawiły się istotne rozbieżności co do zakresu omawianego pojęcia. W języku potocznym przez „szkodę” rozumie się uszczerbek, pomniejszenie, utratę, zarówno w sferze majątkowej, jak i w sferze niemajątkowej ${ }^{4}$. Taka definicja szkody jest najczęściej przyjmowana w nauce prawa cywilnego ${ }^{5}$.

Zgodnie z art. 6 pkt 11 u.z.s.ś.n. przez „,szkodę w środowisku” rozumie się negatywną, mierzalną zmianę stanu lub funkcji elementów przyrodniczych (ocenioną w stosunku do stanu początkowego), która została spowodowana bezpośrednio lub pośrednio przez działalność podmiotu korzystającego ze środowiska. Jak wskazuje się w literaturze przedmiotu, w analizowanym akcie prawnym ustawodawca po raz pierwszy w systemie prawa polskiego zdefiniował pojęcie szkody. Tradycyjnie najwięcej uwagi owemu zagadnieniu poświęca doktryna

wyciek z oczyszczalni „Czajka”, 28.08.2019, Serwis Rzeczypospolitej Polskiej, [online:] https:// www.gov.pl/web/srodowisko/natychmiastowa-reakcja-ministerstwa-na-wyciek-z-oczyszczalniczajka; Komentarz w sprawie awarii w oczyszczalni ścieków Czajka, 29.08.2019, Greenpeace, [online:] https://www.greenpeace.org/poland/komentarze/3547/komentarz-w-sprawie-awarii-woczyszczalni-sciekow-czajka/ [dostęp: 29.12.2020].

3 T.j. Dz.U. 2020, poz. 1740; dalej: k.c.

${ }^{4}$ Zob. Z. Banaszczyk, w: Kodeks cywilny. Komentarz. T. 1: Art. 1-44910. Red. K. Pietrzykowski. Legalis 2020, komentarz do art. 361 k.c., nb. 33.

${ }^{5}$ Zob. np. R. Longchamps de Berier: Zobowiazania. Księgarnia Wydawnicza Gubrynowicz i Syn, Lwów 1938, s. 239; A. Ohanowicz, J. Górski: Zarys prawa zobowiązań. Państwowe Wydawnictwo Naukowe, Warszawa 1970, s. 46; A. Szpunar: Ustalenie odszkodowania w prawie cywilnym. Wydawnictwo Prawnicze, Warszawa 1975; B. Lackoroński: Odpowiedzialność za szkody pośrednie w polskim prawie cywilnym. W: Odpowiedzialność odszkodowawcza. Red. J. Jastrzębski. Wydawnictwo C.H. Beck, Warszawa 2007, s. 140 i nast. 
prawa cywilnego, której poglądy w tym zakresie są uznawane za decydujące o jego rozumieniu. Zaznacza się, że tezy cywilistów odegrały kluczową rolę w definiowaniu szkody także dlatego, iż ustawodawca nie zdecydował się na definicję legalną, uznawszy, że omnis definitio in iure civili periculosa est ${ }^{6}$.

$\mathrm{W}$ analizowanej definicji trzeba jeszcze raz podkreślić, że odnosi się ona tylko do szkód wywołanych przez podmiot korzystający ze środowiska - powstałych w sposób bezpośredni bądź pośredni w wyniku jego działalności. Szkoda ma być zmianą negatywną stanu lub funkcji elementów przyrodniczych w stosunku do stanu początkowego. Ustawą objęto szkody w gatunkach chronionych lub chronionych siedliskach przyrodniczych, w wodach oraz w powierzchni ziemi. Bardzo istotną ich cechą jest mierzalność, a więc możliwość wyrażenia zmian, które nastąpiły, w sposób skwantyfikowany ${ }^{7}$. A contrario - podmiot niezaliczany do podmiotów korzystających ze środowiska nie może wyrządzić szkody w środowisku pojmowanej tak jak w art. 6 pkt 11 u.z.s.ś.n. ${ }^{8}$

Stosownie do treści art. 9 ust. 2 u.z.s.ś.n. w przypadku wystąpienia szkody $\mathrm{w}$ środowisku podmiot korzystający z niego obowiązany jest do:

1) podjęcia działań $\mathrm{w}$ celu ograniczenia szkody $\mathrm{w}$ środowisku, zapobieżenia kolejnym szkodom i negatywnym skutkom dla zdrowia ludzi lub dalszemu osłabieniu funkcji elementów przyrodniczych, w tym do natychmiastowego skontrolowania, powstrzymania, usunięcia lub ograniczenia w inny sposób zanieczyszczeń lub innych szkodliwych czynników;

2) podjęcia działań naprawczych.

W artykule tym nie zostały wymienione konkretne działania, jakie należy przedsięwziąć; pozostawiono to ocenie podmiotu, który ma je wykonywać. Wskazano tylko, że mają zapobiec szkodzie, a jeżeli nie jest to możliwe, to przynajmniej ją zmniejszyć. Mogą być nimi czynności, które mieszczą się w katalogu działań zapobiegawczych wymienionych w art. 6 pkt 4 u.z.s.ś.n., bądź też inne, które w okolicznościach konkretnej sprawy posłużą osiągnięciu celu wyznaczonego przez ustawodawcę9. Ponadto konieczne jest podjęcie czynności, które naprawią zniszczone elementy środowiska lub przywrócą ich funkcję. Trzeba pamiętać, że art. 13 u.z.s.ś.n. wymaga uzgodnienia działań naprawczych $\mathrm{z}$ regionalnym dyrektorem ochrony środowiska na określonych zasadach ${ }^{10}$.

$\mathrm{Na}$ podstawie art. 21 u.z.s.ś.n. podmiot wyrządzający szkodę w środowisku jest obowiązany do ponoszenia wskazanych w ustawie kosztów przeprowadzenia działań zapobiegawczych lub naprawczych. Mowa tu o uzasadnionych

${ }^{6}$ B. Rakoczy: Komentarz do ustawy o zapobieganiu szkodom w środowisku i ich naprawie. LexisNexis, Warszawa 2008, komentarz do art. 6 u.z.s.ś.n., pkt 1.

${ }^{7}$ W. Federczyk, A. Kosieradzka-Federczyk: Ustawa o zapobieganiu szkodom $w$ środowisku i ich naprawie. Komentarz. LEX 2013, komentarz do art. 6 u.z.s.ś.n.

${ }^{8}$ B. Rakoczy: Komentarz do ustawy..., pkt 2.

${ }^{9}$ W. Federczyk, A. Kosieradzka-Federczyk: Ustawa..., komentarz do art. 9 u.z.s.ś.n.

${ }^{10}$ Ibidem. 
kosztach związanych z koniecznością zapewnienia właściwego i efektywnego wykonania rzeczonych działań, w tym o kosztach:

1) gromadzenia danych i oceny bezpośredniego zagrożenia szkodą w środowisku lub szkody w środowisku;

2) opracowania i oceny projektów działań zapobiegawczych lub naprawczych, w tym projektów alternatywnych;

3) przeprowadzenia działań zapobiegawczych lub naprawczych;

4) postępowania administracyjnego;

5) postępowania sądowego;

6) egzekucji;

7) nadzoru i monitoringu;

8) odszkodowań, o których mowa w art. 18 ust. 1 u.z.s.ś.n.

W doktrynie wskazuje się, że problematyka kosztów przeprowadzania działań zapobiegawczych i naprawczych stanowi istotną część analizowanej ustawy. Rozwiązania przyjęte $\mathrm{w}$ tym zakresie są pochodną regulacji dotyczących samych owych działań. Nie można zatem rozpatrywać zasad określających koszty omawianych czynności w oderwaniu od zasad ich podejmowania, gdyż te pierwsze stanowią prostą konsekwencję drugich ${ }^{11}$.

\section{Pokrycie szkód w środowisku w ramach ubezpieczenia OC z tytułu prowadzonej działalności}

Podstawą dalszych rozważań jest fakt, że ubezpieczenie, o którym będzie mowa w tej części artykułu, obejmuje - jak wskazuje sama nazwa - wyłącznie odpowiedzialność cywilną ubezpieczonego (sprawcy) za szkody wyrządzone osobom trzecim, wynikające z czynu niedozwolonego (deliktu) lub/i niewykonania lub nienależytego wykonania zobowiązania (odpowiedzialność kontraktowa).

W kontekście szkód środowiskowych większe znaczenie ma odpowiedzialność deliktowa, która może być oparta na zasadzie winy albo ryzyka lub stanowić odpowiedzialność za produkt niebezpieczny. Wykazanie winy sprawcy może się okazać trudne w odniesieniu do analizowanych tu szkód, gdyż w ich przypadku możliwe są np. planowane działania emisyjne czy ogólne działania zgodne z wydanymi pozwoleniami. Dużo łatwiej przypisać będzie odpowiedzialność na zasadzie ryzyka - tu bowiem ,przyczyną powstania szkody jest [już sam - dop. M.D.] ruch przedsiębiorstwa lub zakładu [...]"12.

${ }^{11}$ Ibidem, komentarz do art. 21 u.z.s.śn.

12 Wyrok SN z dnia 19 czerwca 2001 r., sygn. II UKN 424/00, OSNP 2003, nr 6, poz. 155. 
Nie można oczywiście wykluczyć odpowiedzialności cywilnej kontraktowej za szkody środowiskowe; niemniej wydaje się, że takowe dotyczyć mogą głównie podmiotów projektujących, wykonujących czy świadczących usługi serwisowe dla jednostek, które potencjalnie są źródłem uszczerbku w środowisku. Może się wszak okazać, że w przypadku awarii w oczyszczalni „Czajka” szkody były spowodowane wadliwie zaprojektowaną instalacją lub złym wykonaniem wodociągu czy chociażby niewłaściwie przeprowadzonym przeglądem.

Realizację założeń niniejszej części artykułu trzeba rozpocząć od podania, jak rynek ubezpieczeniowy definiuje szkodę; jest to według niego „szkoda na osobie lub szkoda rzeczowa, a w przypadku roszczenia odpowiedzialności o [!] szkody polegające na powstaniu czystej straty finansowej - także czysta strata finansowa"13. Należy również odnieść się do podziału na szkodę majątkową oraz niemajątkową. Pojęcie szkody majątkowej ma charakter normatywny, a termin ten pojawia się m.in. w przepisach art. $24 \S 2$, art. $43^{10} \mathrm{zd} .2$ oraz art. 438 k.c. Ponieważ k.c. przewiduje też kompensację uszczerbków, które nie mogą być uznane za majątkowe, sformułowano pogląd o potrzebie wyróżnienia w obszarze jego regulacji kategorii obejmującej takie uszczerbki, określane łącznie pojęciem szkody niemajątkowej. W odróżnieniu od szkody majątkowej która stanowi uszczerbek w dobrach i interesach o wartości majątkowej, dających się wyrazić w pieniądzu - szkoda niemajątkowa stanowić ma następstwo naruszenia wartości niemajątkowych, które dotyczą sfery przeżyć człowieka; naruszenie takie powoduje cierpienia fizyczne i/lub psychiczne ${ }^{14}$.

$\mathrm{Z}$ kolei w rozumieniu największego w Polsce towarzystwa ubezpieczeniowego, tj. PZU SA, szkodą na osobie mogą być: „śmierć, uszkodzenie ciała lub rozstrój zdrowia, w tym także utracone korzyści poszkodowanego, które mógłby osiągnąć, gdyby nie doznał uszkodzenia ciała lub rozstroju zdrowia"15. Szkodą rzeczową zaś może być, według PZU SA, ,utrata, zniszczenie lub uszkodzenie rzeczy, w tym także utracone korzyści poszkodowanego, które mógłby osiągnąć, gdyby nie nastąpiła utrata, zniszczenie lub uszkodzenie rzeczy"16. O ile jednak zakres polisy nie zostanie rozszerzony przez włączenie tzw. klauzuli środowiskowej, o tyle ubezpieczyciel nie odpowiada za szkody „powstałe w związku z przedostaniem się niebezpiecznych substancji do powietrza, wody lub gruntu oraz o [!] koszty związane z usunięciem, oczyszczeniem i utylizacją jakichkolwiek zanieczyszczeń" ${ }^{17}$.

Powyższe zapisy Ogólnych Warunków Ubezpieczenia, przytoczone dla czołowego ubezpieczyciela, czyli PZU SA, są powszechną praktyką stosowaną

${ }^{13}$ Ogólne Warunki Ubezpieczenia Odpowiedzialności Cywilnej PZU SA ustalone uchwałą nr UZ/429/2016 z dnia 26 października 2016 r. (dalej: OWU OC PZU), § 6 ust. 21.

${ }_{14}$ Z. Banaszczyk, w: Kodeks cywilny..., nb. 34.

${ }^{15}$ OWU OC PZU, § 6 ust. 22.

${ }^{16}$ OWU OC PZU, § 6 ust. 23.

${ }^{17}$ OWU OC PZU, § 11 ust. 2. 
w OWU wszystkich towarzystw ubezpieczeniowych na polskim rynku. Zbliżona jest również treść rzeczonej klauzuli środowiskowej, zawieranej na standardowych warunkach ubezpieczycieli. W ramach ubezpieczenia OC działalności PZU SA formułuje ową klauzulę następująco:

„1. Z zachowaniem pozostałych, niezmienionych niniejszą klauzulą postanowień OWU oraz za zapłatą dodatkowej składki ubezpieczeniowej strony postanowiły rozszerzyć zakres ubezpieczenia o odpowiedzialność cywilną za szkody powstałe w związku z przedostaniem się niebezpiecznych substancji do powietrza, wody lub gruntu, a także koszty poniesione przez osoby trzecie w celu usunięcia i oczyszczenia z powietrza, wody lub gruntu substancji niebezpiecznej oraz jej utylizacji, pod warunkiem łącznego spełnienia następujących okoliczności:

1) przyczyna przedostania się substancji niebezpiecznej była nagła, przypadkowa, niezamierzona oraz niemożliwa do przewidzenia przez ubezpieczonego;

2) początek procesu przedostania się niebezpiecznych substancji miał miejsce w okresie ubezpieczenia;

3) przedostanie się substancji niebezpiecznej zostało stwierdzone przez ubezpieczonego lub inne osoby w ciągu 168 godzin od chwili rozpoczęcia procesu przedostania;

4) przyczyna procesu przedostania się niebezpiecznych substancji została stwierdzona protokołem służby ochrony środowiska, policji lub straży pożarnej.

2. Przez »przedostanie się niebezpiecznej substancji do powietrza, wody lub gruntu« rozumie się: wprowadzenie bezpośrednie lub pośrednie, wydzielenie, rozrzucenie, rozpylenie, rozlanie, wyciek, wylanie, wtłoczenie, wyrzucenie oraz inne formy uwolnienia niebezpiecznych substancji do powietrza, wody lub gruntu.

3. Przez »substancje niebezpieczne« rozumie się pierwiastki chemiczne i ich związki, mieszaniny i roztwory występujące w środowisku lub powstałe w wyniku działalności człowieka.

4. PZU nie odpowiada $\mathrm{w}$ zakresie wskazanym niniejszą klauzulą za koszty badania, monitorowania i kontroli zanieczyszczenia środowiska"18.

Dla porównania WARTA SA, drugi co do wielkości ubezpieczyciel majątkowy w Polsce, klauzulę środowiskową w ramach ubezpieczenia OC prowadzonej działalności formułuje następująco:

„1. Z zachowaniem pozostałych, niezmienionych niniejszą klauzulą postanowień OWU, w tym wyłączeń określonych w $\S \S 6-8$ OWU, rozszerza się zakres ubezpieczenia o odpowiedzialność cywilną Ubezpieczonego za Szkody osobowe lub Szkody rzeczowe powstałe w związku z Emisją do środowiska.

${ }^{18}$ OWU OC PZU, klauzula nr 6. 
2. WARTA obejmuje ochroną ubezpieczeniową także koszty sprzątania, w tym koszty działań mających na celu ochronę albo usunięcie zagrożenia dla życia, zdrowia lub mienia.

3. W zakresie niniejszej klauzuli WARTA ponosi odpowiedzialność, jeżeli spełnione są łącznie następujące warunki:

1) przyczyna Emisji do środowiska była nagła, niespodziewana i niezależna od woli Ubezpieczonego lub osób, za które ponosi on odpowiedzialność,

2) rozpoczęcie procesu Emisji do środowiska miało miejsce w okresie ubezpieczenia"19.

Na podstawie powyższych przepisów należy stwierdzić, że co do zasady ubezpieczenie odpowiedzialności cywilnej z tytułu prowadzonej działalności rozszerzone o standardową tzw. klauzulę szkód środowiskowych obejmie tylko te szkody, które wystąpiły nagle. Nie należy się zatem spodziewać odpowiedzialności ubezpieczyciela $\mathrm{w}$ ramach takiej polisy w przypadku szkód wyrządzonych przez długotrwałe oddziaływanie na środowisko. Trudno jednak o kompleksową ochronę ubezpieczeniową w tym zakresie, kiedy weźmiemy pod uwagę, że rozszerzenie ochrony o omawianą klauzulę oznacza zwyczajowo koszt od kilkuset do maksymalnie kilku tysięcy złotych (w zależności od wielkości podmiotu, rodzaju i skali działalności).

Kolejnym problemem jest sama specyfika ubezpieczenia odpowiedzialności cywilnej, które pokrywa szkody na osobie lub szkody rzeczowe wyrządzone prowadzoną działalnością. Rozszerzenie ochrony o klauzulę nagłych szkód środowiskowych pozwoli na pokrycie najwyżej roszczeń związanych np. z uszczerbkiem na zdrowiu domowników sąsiadujących z zakładem produkcyjnym, w którym nagle rozszczelniła się instalacja gazu technicznego, czy też roszczeń o koszty naprawy odcinka asfaltu, gdy rozleją się przewożone chemikalia po wypadku środka transportu. Szkodą nie będzie natomiast, zgodnie ze zwyczajową definicją, kompleksowe działanie naprawcze lub zapobiegawcze, objęte reżimem odpowiedzialności administracyjnej. Wydaje się, że przy poważnej szkodzie środowiskowej największym kosztem będzie właśnie przywrócenie środowiska do stanu sprzed szkody, które można ubezpieczyć dzięki specjalnym ubezpieczeniom środowiskowym (sporadycznie możliwe są indywidualne negocjacje odpowiednich klauzul w ubezpieczeniu odpowiedzialności cywilnej).

${ }^{19}$ Ogólne Warunki Ubezpieczenia Odpowiedzialności Cywilnej TUiR „WARTA” SA obowiązujące od dnia 1 marca 2020 r., klauzula nr 2. 


\section{Pokrycie szkód w środowisku w ramach specjalnych ubezpieczeń środowiskowych}

Tak zwane ubezpieczenie środowiskowe obejmuje ochroną wyłącznie szkody w środowisku oraz ich następstwa (w zakresie przewidzianym przez dane towarzystwo ubezpieczeniowe). Zwyczajowo ochroną objęta jest odpowiedzialność zarówno cywilna, jak i administracyjna sprawcy zdarzenia, co wydaje się kluczowe, gdyż „odpowiedzialność administracyjna chroni interes publiczny, postępowanie może zostać wszczęte $\mathrm{z}$ urzędu i jest to postępowanie szybsze, cechujące się mniejszym formalizmem. Organem właściwym do orzeczenia o odpowiedzialności jest organ administracji publicznej”20. Co istotne, w odróżnieniu od ubezpieczenia odpowiedzialności cywilnej, w ubezpieczeniu środowiskowym zakresem ochrony objęte są również (a właściwie przede wszystkim) szkody wynikające z powolnego oddziaływania na środowisko. Dla przykładu, przedmiotem takiego ubezpieczenia oferowanego przez STU ERGO Hestia SA są:

„a) odpowiedzialność administracyjna Ubezpieczonego wynikająca ze spowodowania bezpośredniego zagrożenia szkodą w środowisku lub szkody w środowisku, włączając w to odpowiedzialność z tytułu roszczeń osób trzecich o zwrot poniesionych przez nie kosztów działań zapobiegawczych i naprawczych;

b) odpowiedzialność cywilna Ubezpieczonego względem osób trzecich za będące następstwem emisji szkody $\mathrm{w}$ mieniu, na osobie oraz czyste straty finansowe" 21 .

Z kolei zakresem ubezpieczenia środowiskowego w STU ERGO Hestia SA objęte są: „koszty działań zapobiegawczych, koszty działań naprawczych, szkody w mieniu i na osobie będące następstwem emisji, czyste straty finansowe będące następstwem emisji polegające na utracie możliwości korzystania z rzeczy"22.

Inny ubezpieczyciel, Colonnade Insurance, w ramach ubezpieczenia środowiskowego zapewnia ochronę w przypadku:

„1) nieoczekiwanych i niezamierzonych Szkód, za które Ubezpieczony zostanie zobowiązany do zapłaty z tytułu Roszczeń dotyczących:

${ }^{20}$ J.J. Skoczylas: Pojęcie i rodzaje odpowiedzialności prawnej $w$ ochronie środowiska. „Zeszyty Naukowe Szkoły Głównej Służby Pożarniczej” 2011, nr 41, s. 121.

${ }^{21}$ Ogólne Warunki Ubezpieczenia Odpowiedzialności za Szkody w Środowisku STU ERGO Hestia SA z dnia 24 września 2018 r. (dalej: OWU OC ERGO Hestia), § 1 ust. 1.

${ }^{22}$ OWU OC ERGO Hestia, § 1 ust. 2. 
a) Szkody Osobowej lub Szkody na Mieniu - poniesionych przez osoby trzecie i wynikających z Emisji rozpoczętej po Dacie Retroaktywnej i powstałej w wyniku Ubezpieczonej Działalności;

b) Kosztów Czyszczenia wynikających ze Szkody w Środowisku rozpoczętej po Dacie Retroaktywnej i powstałej w wyniku Ubezpieczonej Działalności;

2) Kosztów Przerwy w Działalności spowodowanych bezpośrednio przez Emisję rozpoczętą po Dacie Retroaktywnej i powstałą w granicach (w tym w gruntach) posiadanych, najmowanych lub dzierżawionych przez Ubezpieczonego miejsc prowadzenia Ubezpieczonej Działalności;

3) Kosztów Obrony lub Kosztów Minimalizacji wynikających z Emisji lub Szkody w Środowisku rozpoczętych po Dacie Retroaktywnej”"23.

Powyższa analiza przykładowych OWU wskazuje na dużo szersze pokrycie ochroną ubezpieczeniową ustawowej odpowiedzialności sprawcy szkody w środowisku przez specjalne ubezpieczenie aniżeli przez samą klauzulę w ubezpieczeniu odpowiedzialności cywilnej. Co więcej, w przypadku STU ERGO Hestia SA oraz Colonnade Insurance (a powoli staje się to standardem na rynku) część zakresu ubezpieczenia pokrywa zwyczajową treść klauzul stosowanych w ubezpieczeniu OC prowadzonej działalności, dzięki czemu po zawarciu takiej polisy na ogół nie ma konieczności rozszerzenia owej polisy OC.

W ramach specjalnych polis środowiskowych co do zasady można zatem liczyć na pokrycie kosztów nie tylko badań środowiskowych, ekspertyz, analiz, lecz także samej rekultywacji środowiska czy monitorowania jego stanu po szkodzie. Dla sprawcy szkody istotne może być również ewentualne skorzystanie z pokrycia kosztów doradztwa czy pomocy prawnej po zdarzeniu, za co zapłaci (po wcześniejszej akceptacji) ubezpieczyciel. Ponadto warto pamiętać, że skoro ubezpieczenie, któremu poświęcona jest niniejsza część artykułu, dotyczy tylko szkód środowiskowych, nie ma możliwości wyczerpania sumy ubezpieczenia przez inne zdarzenia, niewykluczonego w przypadku ubezpieczenia odpowiedzialności cywilnej z tytułu prowadzonej działalności. Jak jednak łatwo się domyślić, odrębne ubezpieczenia środowiskowe, które zapewniają bardziej wszechstronną ochronę, są zdecydowanie droższe niż rozszerzenie ubezpieczenia odpowiedzialności cywilnej o klauzulę nagłych szkód środowiskowych - co do zasady składki w skali roku rozpoczynają się od poziomu $10000 \mathrm{zł.}$

${ }^{23}$ Ogólne Warunki Ubezpieczenia Odpowiedzialności za Szkody w Środowisku Colonnade Insurance Societe Anonyme, Oddział w Polsce, zatwierdzone w dniu 20 września 2018 r., § 2 ust. 2. 


\section{Podsumowanie}

W artykule przytoczone zostały wybrane zagadnienia związane ze szkodami w środowisku oraz możliwością ich pokrycia w ramach polis oferowanych na polskim rynku ubezpieczeniowym. Ustawa o zapobieganiu szkodom w środowisku i ich naprawie w precyzyjny sposób określa zakres odpowiedzialności sprawcy szkody oraz nakłada na niego szereg obowiązków, których realizacja będzie bez wątpienia kosztowna. Przedsiębiorcy, samorządy, ale i wszyscy konsumenci codziennie ponoszą ryzyko wyrządzenia szkody w środowisku. Niniejszy tekst przedstawia praktyczne spojrzenie na sposoby ubezpieczenia podmiotów instytucjonalnych.

$\mathrm{Z}$ jednej strony ustawodawstwo, $\mathrm{z}$ drugiej warunki konkretnego ubezpieczenia determinują rzeczywistą możliwość wypłaty odszkodowania na naprawę uszczerbków w środowisku. Świadomość chociażby podstawowych różnic pomiędzy zakresem ubezpieczenia odpowiedzialności cywilnej prowadzonej działalności rozszerzonego o klauzulę szkód środowiskowych a zakresem specjalnego ubezpieczenia środowiskowego pozwoli na podjęcie bardziej przemyślanych decyzji dotyczących programu ubezpieczenia danej firmy czy samorządu. Potencjalne koszty ubezpieczenia środowiskowego w przypadku większości instytucji będą bowiem stanowić niewielki procent ogólnej sumy składek, tymczasem zapewniają szeroki zakres ochrony $\mathrm{w}$ razie ewentualnego zaistnienia szkody.

\section{Literatura}

Banaszczyk Z., w: Kodeks cywilny. Komentarz. T. 1: Art. 1-449 10 . Red. K. Pietrzykowski. Legalis 2020 .

Federczyk W., Kosieradzka-Federczyk A.: Ustawa o zapobieganiu szkodom w środowisku i ich naprawie. Komentarz. LEX 2013.

Lackoroński B.: Odpowiedzialność za szkody pośrednie w polskim prawie cywilnym. W: Odpowiedzialność odszkodowawcza. Red. J. Jastrzębski. Wydawnictwo C.H. Beck, Warszawa 2007.

Longchamps de Berier R.: Zobowiąania. Księgarnia Wydawnicza Gubrynowicz i Syn, Lwów 1938.

Ohanowicz A., Górski J.: Zarys prawa zobowiąań. Państwowe Wydawnictwo Naukowe, Warszawa 1970.

Rakoczy B.: Komentarz do ustawy o zapobieganiu szkodom w środowisku i ich naprawie. LexisNexis, Warszawa 2008.

Skoczylas J.J.: Pojęcie i rodzaje odpowiedzialności prawnej w ochronie środowiska. „Zeszyty Naukowe Szkoły Głównej Służby Pożarniczej” 2011, nr 41, s. 119-132. 
Szpunar A.: Ustalenie odszkodowania w prawie cywilnym. Wydawnictwo Prawnicze, Warszawa 1975.

Źródła elektroniczne

Komentarz w sprawie awarii w oczyszczalni ścieków Czajka, 29.08.2019, Greenpeace, [online:] https://www.greenpeace.org/poland/komentarze/3547/komentarz-w-sprawie-awarii-woczyszczalni-sciekow-czajka/ [dostęp: 29.12.2020].

Natychmiastowa reakcja Ministerstwa na wyciek z oczyszczalni „Czajka”, 28.08.2019, Serwis Rzeczypospolitej Polskiej, [online:] https:/www.gov.pl/web/srodowisko/natychmiastowareakcja-ministerstwa-na-wyciek-z-oczyszczalni-czajka [dostęp: 29.12.2020].

Pilne! Kolejna awaria w oczyszczalni ścieków „Czajka” w Warszawie, 11.12.2020, Państwowe Gospodarstwo Wodne „Wody Polskie”, [online:] https://www.wody.gov.pl/aktualnosci/1290pilne-kolejna-awaria-w-oczyszczalni-sciekow-czajka-w-warszawie [dostęp: 29.12.2020].

Marceli Drabek

\title{
Practical possibilities to cover damages in the environment by insurance on the polis insurance market - selected issues
}

\author{
Summary
}

The article deals with selected aspects of liability for environmental damage in Polish legislation and the possibility of insuring them under the policies operating on the Polish market. The author notes that the main legal act regulating liability for environmental damage is the Act of April 13, 2007 on the prevention and repair of environmental damage. The main aim of the publication is to present the possibility of covering the selected damages with civil liability insurance for the conducted activity or specialist environmental insurance, based on market examples.

Key words: environmental damages, civil liability, civil liability insurance, environmental insurance

\section{Марцелий Драбек}

\section{Практические возможности возмещения экологического ущерба на польском рынке с помощью страхования экологических рисков - избранные вопросы}

Резюме

В статье рассматриваются некоторые аспекты ответственности за экологический ущерб в польском законодательстве и возможности страхования экологических рисков в рамках полисов, доступных на польском рынке. Автор отмечает, что основным правовым актом, регулирующим ответственность за нанесение вреда окружающей среде, является Закон от 13 апреля 2007 года о предотвращении экологического ущерба и его возмещении. Основная цель публикации - описать возможность возмещения указанного 
выше ущерба с помощью страхования гражданской ответственности в связи с осуществляемой деятельностью или специализированного экологического страхования на основе доступных предложений на рынке.

Ключевы е слова: экологический ущерб, гражданская ответственность, страхование гражданской ответственности, экологическое страхование

Marceli Drabek

\title{
Possibilità pratiche di copertura assicurativa dei danni ambientali sul mercato polacco - questioni selezionate
}

\author{
Sommario
}

L'articolo riguarda alcuni aspetti selezionati della responsabilità per danni ambientali nella legislazione polacca e la possibilità di assicurarli nell'ambito delle polizze operanti nel mercato polacco. L'autore nota che il principale atto giuridico che regola la responsabilità per il danno ambientale è la legge del 13 aprile 2007 sulla prevenzione e la riparazione dei danni ambientali. Lo scopo principale di questa pubblicazione è presentare le possibilità di coprire i suddetti danni con un'assicurazione di responsabilità civile per attività commerciali o un'assicurazione ambientale specializzata, utilizzando esempi di mercato.

Parole chiave: danni ambientali, responsabilità civile, assicurazione di responsabilità civile aziendale, assicurazione ambientale 